\title{
A new species of Dichaea (Orchidaceae) for northern Brazil
}

\author{
Jefferson José VALSKOํㅗ ${ }^{1}$ Amauri Herbert KRAHL ${ }^{2 *}$, Ana Sofia Sousa de HOLANDA², \\ Charles Eugene ZARTMAN² \\ 1 Universidade Federal do Amazonas, Programa de Pós-Graduação em Diversidade Biológica, Rua Gal. Rodrigo Otávio Jordão Ramos, 3000, Japiim I, Manaus, AM, Brasil. \\ 2 Instituto Nacional de Pesquisas da Amazônia, Programa de Pós-Graduação em Botânica, Av. André Araújo, 2936, Aleixo, Manaus, AM, Brasil. \\ * Corresponding author: amaurikrahl@hotmail.com
}

\section{ABSTRACT}

Dichaea is the largest genus of the subtribe Zygopetalinae and holds it's the highest species diversity in South America. Therefore, this study aims to describe a new species of Dichaea, which occurs in northern Brazil, Dichaea bragae Valsko, Krahl \& Holanda. The new species was collected in the north of Manaus in an area of ombrophilous forest and flowered when cultivated. The epithet honors Dr. Pedro Ivo Soares Braga (in memoriam), orchidologist who conducted several studies in the Brazilian Amazon. This new species show a affinity with Dichaea tenuis C. Schweinf., however it is differentiated both vegetatively and on labellum morphology.

KEYWORDS: Taxonomy, Amazonas, epiphyte, dense ombrophilous forest.

\section{Uma nova espécie de Dichaea (Orchidaceae) para o norte do Brasil}

\section{RESUMO}

Dichaea é o maior gênero da subtribo Zygopetalinae e possui sua maior diversidade de espécies na América do Sul. Diante disto, este trabalho teve o objetivo de descrever uma nova espécie de Dichaea ocorrente na região norte do Brasil, Dichaea bragae Valsko, Krahl \& Holanda. A nova espécie foi coleta ao norte de Manaus em área de floresta ombrófila e floresceu em cultivo. O epíteto é em homenagem ao Dr. Pedro Ivo Soares Braga (in memorian), orquidólogo que realizou vários estudos na Amazônia brasileira. A nova espécie possui afinidade com espécies de Dichaea seção Dichaeopsis, contudo são diferenciadas vegetativamente e na morfologia do labelo.

PALAVRaS ChaVE: Taxonomia, Amazonas, epífita, floresta ombrófila densa. 
The genus Dichaea was described by Lindley (1833) and holds the largest number of species belonging to the subtribe Zygopetalinae (Chase et al. 2003; Whitten et al. 2005) and comprises nearly 100 species (Pupulin 2007) distributed from Mexico to Bolivia and Argentina as well as the West Indies, presenting its highest diversity in South America (Dodson 2004). Ecuador presents 40 species recorded in the genus (Dodson 2004), Costa Rica hosts 29 species (Pupulin 2007) and Brazil 25 species, with 11 of them being endemic, as well as 18 documented species in the Brazilian Amazon (Barros et al. 2013). Fourteen of the latter are to be found in the state of Amazonas (Barros et al. 2013).

Since the original description of the genus, other taxonomic treatments including: e.g. Cogniaux (1904-1906); Folsom (1987); Folsom (1996). Presently, four sections are recognized for the genus Dichaea (Cogniaux 1904-1906): Dichaea section Dichaea, which presents pilous ovary and non-articulate leaves; Dichaea section Dichaeastrum, with glabrous ovary and non-articulate leaves; Dichaea section Dichaeopsis, which involves plants presenting glabrous ovary and articulate leaves; and finally, Dichaea section Pseudodichaea, characterized by the pilous ovary and articulate leaves. Pabst and Dungs (1977) divided the genus into five groups taking the leaves (articulation and deciduousness), ovary (glabrous or pilous) and labellum characteristics into account. Even though this genus treatments are limited to Brazilian species, its sections comprise all aforementioned authors combinations for the genus, as a whole. The present study aims to describe a new species of Dichaea: Dichaea bragae Valsko, Krahl \& Holanda. The terminology used to describe the characteristics is based on Radford et al. (1974) and Dressler (1993).

Dichaea bragae Valsko, Krahl \& Holanda, sp. nov. Type: BRASIL: Amazonas: Manaus, BR 174, KM 72, Projeto Dinâmica Biológica de Fragmentos Florestais (PDBFF), Fazenda Dimona, S $2^{\circ} 21^{\prime}$ and W 59 ${ }^{\circ} 57^{\prime}, 7 / \mathrm{V} / 2012$, fl., flowered in cultivation in 7.IV.2013, J.J. Valsko 108 (Holotype INPA). (Figure 1A-E, Figure 2A-D).

Dichaea bragae is similar to $D$. tenuis yet they differentiate by the fact that $D$. bragae holds elliptical leaves with apiculate apex being wider than those of $D$. tenuis that presents aciculate and semiterete leaves. Furthermore, D. bragae presents elliptical sepals and petals and the labellum lateral lobes show to be sharply curved, being that $D$. tenuis presents ovate sepals and petals and round labellum lobes. The labellum lateral lobes curvature is similar to that of D. cornuta, however, the latter presents larger floral parts.

The plant is epiphytic and cespitose. Its roots are between 1.5 and $1.8 \mathrm{~mm}$ in diameter and whitish, slightly fleshed and emerge from the stem base. The stem is from 4.3 to $20.6 \mathrm{~cm}$ long and nearly $3.3 \mathrm{~mm}$ in diameter and shows to be lengthy and not branched, cylindrical-shaped and to be covered by leaf sheaths. These leaf sheaths are about $12.2 \mathrm{~mm}$ long and $3.6 \mathrm{~mm}$ in width, are glabrous with entire margin and light green coloring. Leaves are near $22 \mathrm{~mm}$ long and 5.6 $\mathrm{mm}$ in width, are elliptical-shaped with rounded base and apiculate apex. Leaf blades present articulate base with leaf sheaths and are spaced among one on other, in addition to presenting themselves as deciduous, glabrous, entire margin and light green colored. The inflorescence is one-flowered, solitary and with $6.8 \mathrm{~mm}$ long, in addition to emerging from in between the leaf sheaths. The pedicel is about 3.83 $\mathrm{mm}$ long and shows to be glabrous with two tubular bracts on its base. Both bracts have sharp apex, entire margin and are slightly greenish white- colored. The outer bract measures about $2.9 \mathrm{~mm}$ long and $1.1 \mathrm{~mm}$ in width and the inner one $2.8 \mathrm{~mm}$ long and $1.1 \mathrm{~mm}$ in width. The ovary and pedicel together measure about $1 \mathrm{~mm}$ long and $0.3 \mathrm{~mm}$ in width and are glabrous. Flowers are green-colored on the sepals and petals and the labellum is white. Flowers didn't put forth no aroma at all. The dorsal sepal measures about $3.6 \mathrm{~mm}$ long and $1.2 \mathrm{~mm}$ in width and is lanceolate-shaped, acute-apexed and round-based, in addition to being symmetrical and with entire margin. Lateral sepals have about $4.9 \mathrm{~mm}$ long and $1.9 \mathrm{~mm}$ in width and likewise shaped. Petals measure near $4.1 \mathrm{~mm}$ long and $1.7 \mathrm{~mm}$ in width, lanceolate-shaped, acute apex and round-based as well, in addition to being slightly asymmetrical and with entire margin. The labellum measures about $4.3 \mathrm{~mm}$ long and $3.7 \mathrm{~mm}$ in width and shows to be 3-lobed. Its base is unguiculate, oblong and measures nearly $2.3 \mathrm{~mm}$ long and $0.4 \mathrm{~mm}$ in width, in addition to being glabrous and with entire margin. The labellum blade have about $2.5 \mathrm{~mm}$ long and $3.7 \mathrm{~mm}$ in width, is triangular and apiculate-apexed. The labellum lateral lobes are linear and sharp-curved, round-apexed and with entire margin. The gynostemium is near $1 \mathrm{~mm}$ long and $0.6 \mathrm{~mm}$ in width, is erect and glabrous. The anther cap measures approximately $1.6 \mathrm{~mm}$ long and $1.4 \mathrm{~mm}$ in width, being round, symmetrical, glabrous, with entire margin and green-colored. The species presents four pollinia being two different pairs. The pollinia measures about $0.1 \mathrm{~mm}$ in diameter and are yellowish-colored and circular-shaped. The stipe is triangular in dorsal view and the viscidium is elliptical. The fruit is about $7.5 \mathrm{~mm}$ long and $2.5 \mathrm{~mm}$ in width, glabrous, ovate and light green-colored.

Etymology, phenology, distribution and habitat: the epithet honors Dr. Pedro Ivo Soares Braga (in memoriam), orchidologist who developed several studies with Orchidaceae in the Brazilian Amazon (Storti 2011). It flowered in cultivation between March and May. The flowers last approximately three days. Dichaea bragae occurs in dense ombrophilous forest at an altitude of 90-100 meters in the Dimona farm belonging to the Biological Dynamics of Forest Fragments Project (PDBFF). The type specimen was found in an area where flooding occurs for a short period, resulting in 

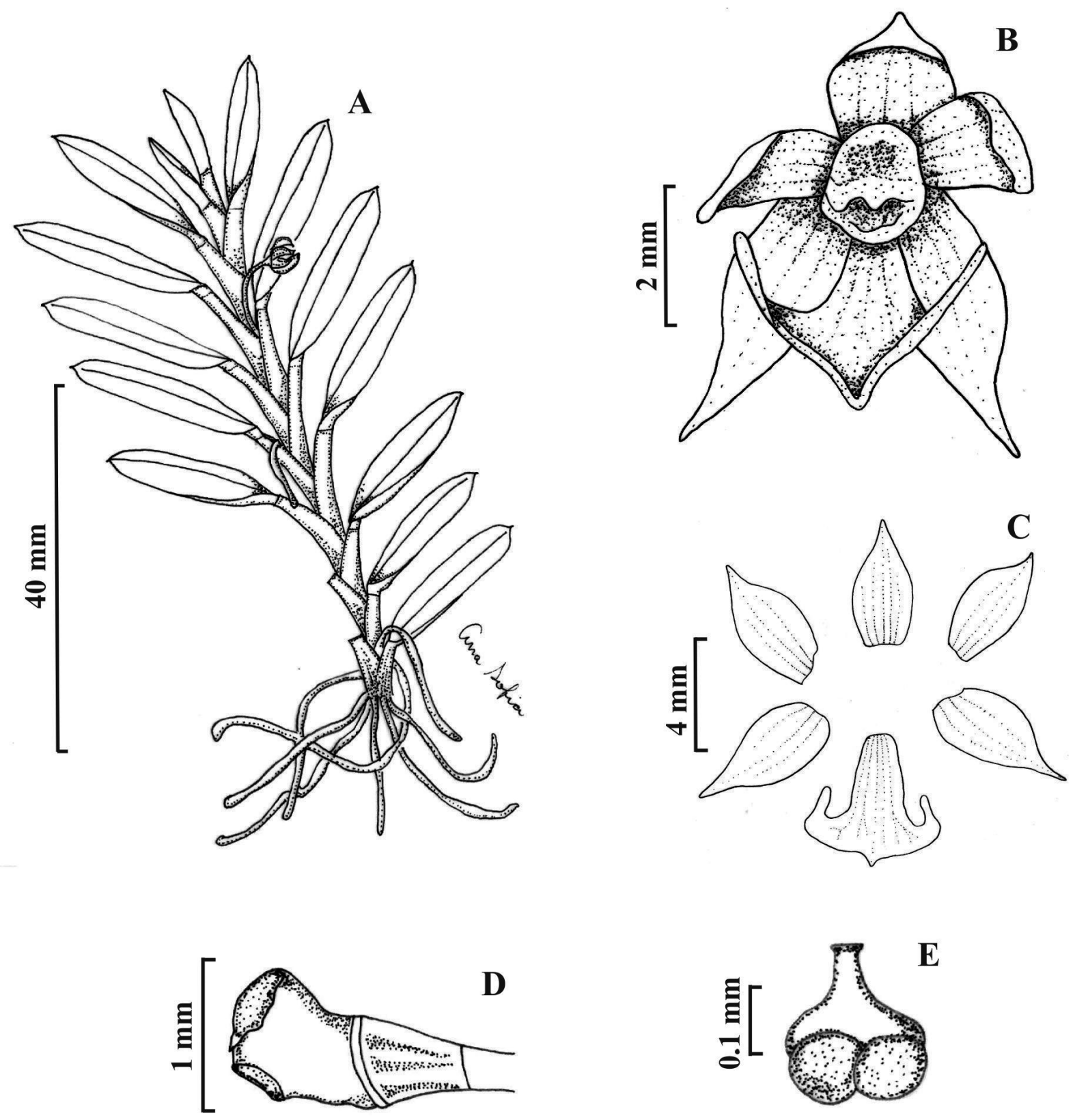

Figure 1. Dichaea bragae Valsko, Krahl \& Holanda. A. General aspect of the plant. B. Flower. C. Floral parts. D. Gynostemium. E. Pollinia.

the formation of small ponds within the forest. It is observed attached to the phorophytes, about four to eight meters from the ground in low light environment.

Comments: Dichaea bragae presents morphological characteristics that fit within the Dichaea section Dichaeopsis (Cogniaux 1904-1906). The species fits in the D. panamensis group, According to Pabst and Dungs (1977), the plants of which always hold articulated and deciduous leaves, glabrous ovary and a narrow and long labellum base. This species is related to Dichaea tenuis C. Schweinf., however it differs both in the vegetative aspect and floral morphology (labellum). Dichaea bragae presents apiculate-apexed, elliptical leaves, larger (ca. $5.64 \mathrm{~mm}$ ) than those of $D$. tenuis which present 9-11 mm wide and acuminate-apexed semiterete acicular 


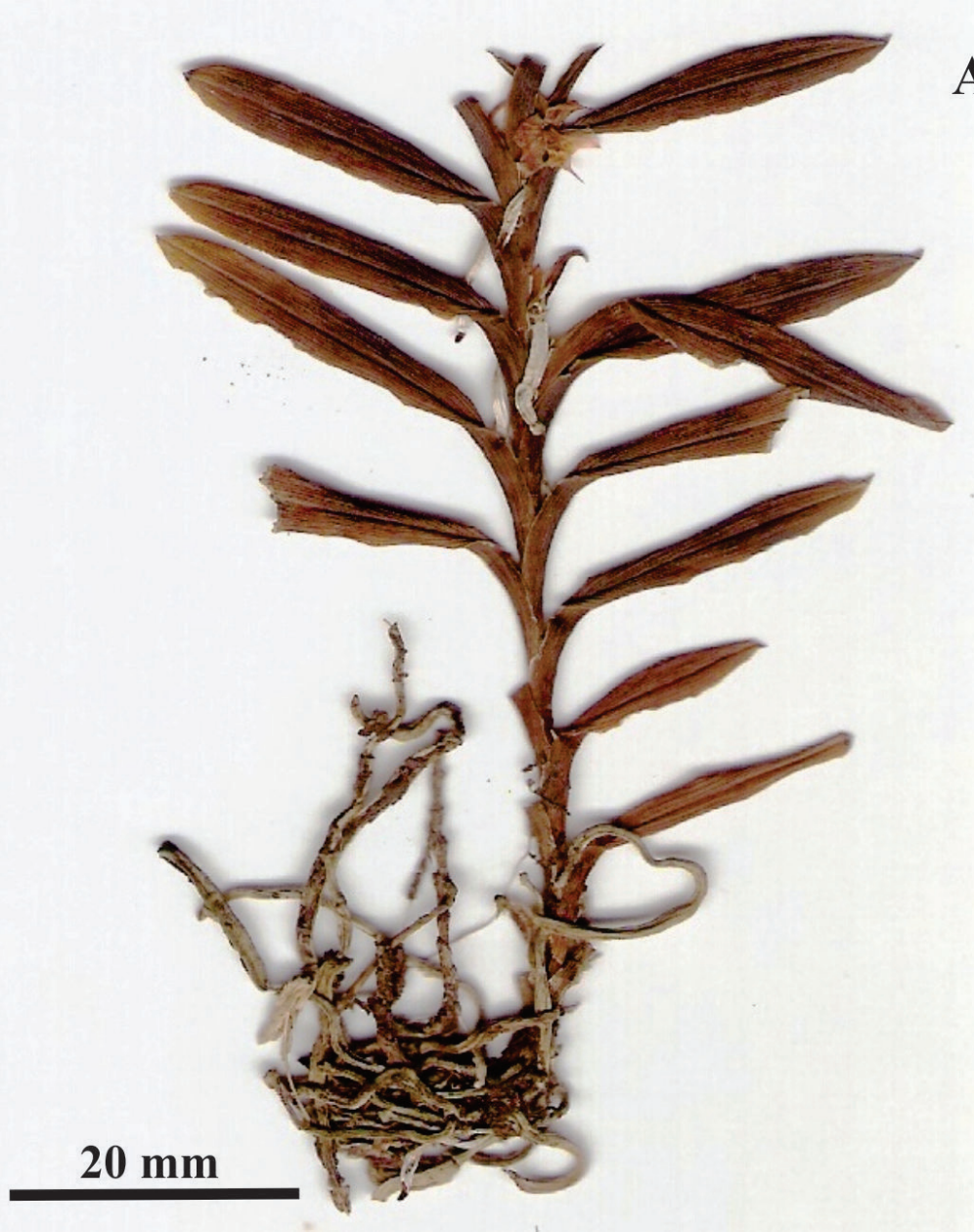

A
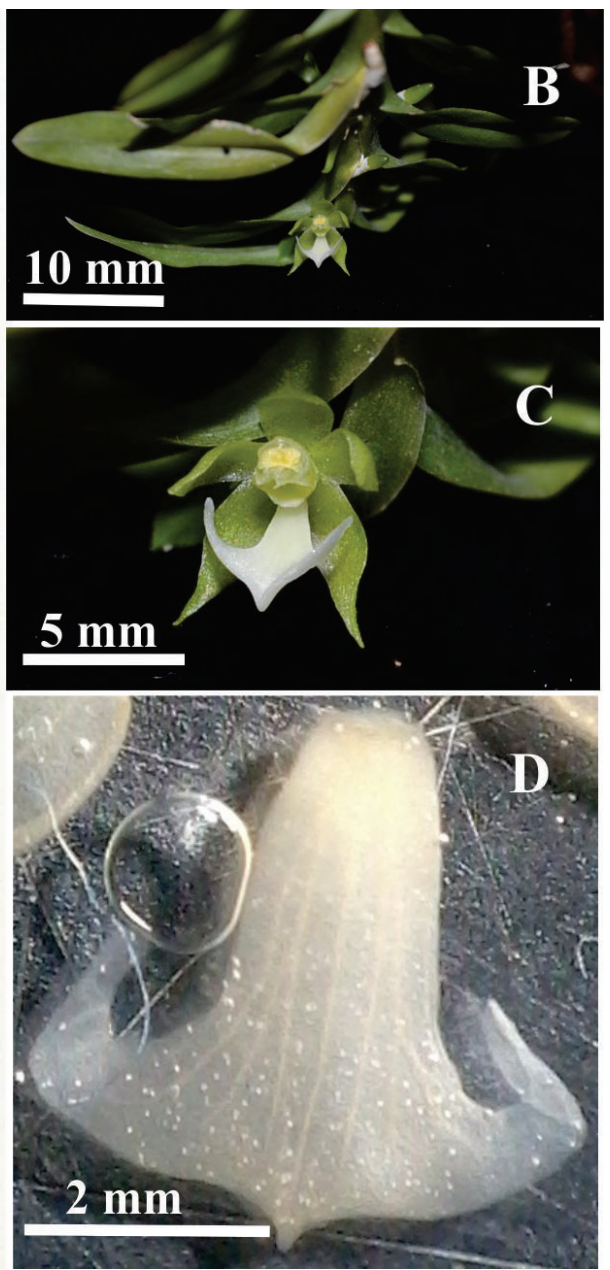

Figure 2. Dichaea bragae Valsko, Krahl \& Holanda. A. General aspect of holotype. B. Image of the plant. C. Flower. D. Labellum.

leaves, h. The floral parts (sepals and petals) of D. bragae are lanceolate while in $D$. tenuis they are ovate, in addition, the $D$. bragae labellum holds linear, sharp-curved, side lobes while the $D$. tenuis labellum is widely rounded (Schweinfurth 1961). In general, the curvature of the side lobes in D. bragae is the main characteristic distinguishing this species from all other she in the same genus. However, in addition to D. bragae, the species Dichaea cornuta S. Moore also presents sharp-curved lateral lobes, yet $D$. bragae holds smaller floral parts (sepals, petals and lip) (e.g. dorsal sepals $=3.6 \mathrm{~mm}$, labellum $=4.3$ $\mathrm{mm}$ ) than those of $D$. cornuta by having larger floral parts (e.g. dorsal sepals $=8.5 \mathrm{~mm}$, labellum $=6 \mathrm{~mm}$ ). In the phylogenetic of Neubig et al. (2009) the Dichaea section Dichaeopsis is shown to form some clades bearing closely related species. Dichaea trulla Rchb. f. that resembles vegetatively with $D$. bragae being one Among them, and Dichaea glauca (Sw.) Lindl is mentioned to be among them as well. However the sharp curve in $D$. bragae lateral lobes clearly differs from that present in D. trulla and D. glauca.

\section{ACKNOWLEDGMENTS}

The authors acknowledge the Biological Dynamics of Forest Fragments Project (PDBFF) for all the logistics provided; and graduate program in botany from the National Institute of Amazonian Research (INPA) for the support provided.

\section{REFERENCES}

Barros, F.; Vinhos, F.; Rodrigues, V.T.; Barberena, F.F.V.A.; Fraga, C.N.; Pessoa, E.M.; Foster, W.; et al. (Orgs.). Lista das espécies da flora do Brasil. Jardim Botânico do Rio de Janeiro, Rio de Janeiro. (http://floradobrasil.jbrj.gov.br). Accessed on 29/09/2013.

Chase, M.W.; Freudenstein, J.V.; Cameron, K.M.; Barrett, R.L. 2003. DNA data and Orchidaceae systematics: a new 
phylogenetic classification. In: Dixon, K.W.; Kell, S.P.; Barrett, R.L.; Cribb, P.J. (Eds.). Orchid conservation. Kota Kinabalu, Natural History Publications, p. 69-89

Cogniaux, A. 1904-1906. Orchidaceae. In: Martius, C.F.P.; Eichler, A.G.; Urban, I. (Eds.). Flora Brasiliensis. v. 3. F. Fleischer, Munich, p. 1-604.

Dodson, C. H. 2004. Rodriguezia-Zygosepalum. In: Dodson, C. H. (Ed.). Native Ecuadorian Orchids. v. 5, Sarasota, 232 p.

Dressler, R.L. 1993. Phylogeny and Classification of the Orchid Family. Dioscorides Press, Portland, 1993, 314p.

Folsom, J.P. 1987. A Systematic monograph of Dichaea section Dichaea (Orchidaceae). PhD Thesis, University of Texas, Austin. 266p.

Folsom, J.P. 1996. An introduction to the genus Dichaea and a synopsis of section Dichaea. Orchid Digest, 60: 148-155.

Lindley, J. 1833. The genera and species of orchidaceous plants. Ridgways, London, 554p.

Neubig, K.M.; Williams, N.H.; Whitten, W.M.; Pupulin F. 2009. Molecular phylogenetics and the evolution of fruit and leaf morphology of Dichaea (Orchidaceae: Zygopetalinae). Annals of Botany, 104: 457-467.

Pabst, G.F.J.; Dungs, F. 1977. Orchidaceae Brasiliensis. v.2. Hildesheim, Kurt Scmersow, Germany, 418p.
Pupulin F. 2007. Contributions toward a reassessment of Costa Rican Zygopetalinae (Orchidaceae). 3. A systematic revision of Dichaea in Costa Rica. Journal of the Arnold Arboretum, 12: 15-153.

Radford, A.E.; Dickinson, W.C.; Massey, J.R.; Bell, C.R. 1974. Vascular plants systematic. Haper \& Row, New York, 891p.

Schweinfurth, C. 1961. Orchids of Peru. Fieldiana, Botany, 30: 787-1026.

Storti, E. 2011. Memória: Pedro Ivo Soares Braga. Acta Amazonica, 41: 333-334.

Whitten, W.M.; Williams, N.H.; Dressler, R.L.; Gerlach, G.; Pupulin, F. 2005. Generic relationships of Zygopetalinae (Orchidaceae: Cymbidieae): combined molecular evidence. Lankesteriana, 5: 87-107.

Recebido em 23/10/2013

Aceito em 12/02/2014 
